\title{
Pengaruh Latihan Interval Intensitas Tinggi terhadap Denyut Nadi Mahasiswa Kedokteran
}

\author{
Raden Ayu Tanzila, Milla Fadliya Bustan \\ Departemen Fisiologi, Fakultas Kedokteran, Universitas Muhammadiyah Palembang
}

\begin{abstract}
Abstrak
Riset dasar kesehatan (2007) menyatakan bahwa 48,2\% penduduk Indonesia yang berusia lebih dari 10 tahun kurang melakukan aktivitas fisik dengan kelompok perempuan lebih tinggi daripada laki-laki. Fakultas Kedokteran Universitas Muhammadiyah Palembang menggunakan program student centered untuk mahasiswanya yang menyebabkan kesibukan belajar yang sangat padat sehingga mahasiswa kurang melakukan aktivitas fisik. Penelitian ini bertujuan mengetahui pengaruh latihan interval intensitas tinggi terhadap denyut nadi mahasiswa Fakultas Kedokteran Universitas Muhammadiyah Palembang selama periode November 2015-Februari 2016. Latihan interval intensitas tinggi ialah bentuk latihan kombinasi latihan intensitas tinggi dengan intensitas sedang atau rendah dalam selang waktu tertentu dengan efek sama dengan latihan intensitas sedang, namun tidak memerlukan waktu yang banyak. Data didapatkan dari pengukuran denyut nadi secara langsung sebelum dan setelah melakukan latihan interval intensitas tinggi pada 60 mahasiswa Fakultas Kedokteran Universitas Muhammadiyah Palembang yang memenuhi kriteria inklusi. Data diolah menggunakan uji T-dependent dan uji normalitas Shapirowilk. Didapatkan denyut nadi subjek meningkat setelah latihan interval intensitas tinggi. Denyut nadi rata-rata sebelum

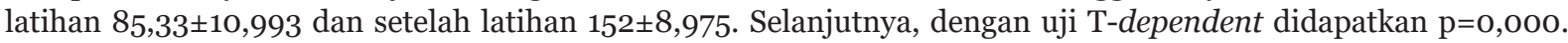
Simpulan, terdapat pengaruh latihan interval intensitas tinggi terhadap denyut nadi pada mahasiswa Fakultas Kedokteran Universitas Muhammadiyah Palembang.
\end{abstract}

Kata kunci: Denyut nadi, latihan interval intensitas tinggi, mahasiswa kedokteran

\section{Effect of High Intensity Interval Training on Pulse Rate in Medical Students}

\begin{abstract}
Indonesia basic health research (2007) states that $48.2 \%$ of the Indonesian population aged over 10 years have less physical activity with women having less than men. Faculty of Medicine University Muhammadiyah Palembang used student centered learning which required long learning hours that can cause students to have less time for physical exercise. This study aims to determine the effects of high intensity interval training to pulse rate on students of Faculty of Medicine University Muhammadiyah Palembang. Data collected during November 2015 to February 2016. High intensity interval training is a form of exercise that combine high-intensity exercise with moderate or low intensity in a certain time interval. It has the same effect with moderate intensity exercise. However, it does not require a lot of time. The data was obtained from pulse rate measurement directly before and after high intensity interval training to 60 students. The data was processed using T-dependent test and Shapiro Wilk normality test. The mean of pulse rate before and after the high intensity interval training were $85.33 \pm 10.993$ and $152 \pm 8.975(\mathrm{p}=0.000)$ respectively. Therefore, there was clearly an increase of pulse rate after high intensity interval training. In conclusion, there was the effect of high intensity interval training to pulse rate on students at Faculty of Medicine of University of Muhammadiyah Palembang.
\end{abstract}

Key words: High intensity interval training, pulse rate, medical students

Korespondensi: Raden Ayu Tanzila, dr., M.Kes. Departemen Fisiologi, Fakultas Kedokteran, Universitas Muhammadiyah Palembang. Jl. KH. Balqhi/Talang Banten No. 13 Ulu, Palembang. HP: 082184444373. Telepon: 0711-520045. Faksimile: 0711516899.E-mail: ratanzila247@gmail.com 


\section{Pendahuluan}

Latihan interval intensitas tinggi adalah bentuk latihan sistem jantung yang mempergunakan kombinasi latihan intensitas yang tinggi dengan intensitas yang sedang atau rendah dalam selang waktu tertentu. Latihan interval intensitas tinggi merupakan bentuk latihan sistem jantung yang menggunakan kombinasi latihan intensitas tinggi dengan intensitas yang sedang atau rendah dalam selang periode tertentu. Latihan ini merupakan salah satu latihan aerobik untuk membakar kalori dan meningkatkan kekuatan, daya tahan, serta kebugaran fisik. Pelatihan interval ini dilakukan dengan interval yang tinggi selama 4-30 menit untuk latihan sistem kardiovaskular, kemudian dilakukan bergantian dengan latihan intensitas rendah. Porsi melakukan latihan intensitas tinggi dan latihan intensitas rendah harus dilakukan dengan rentang waktu yang sama. ${ }^{1-3}$

Denyut nadi itu merupakan gambaran denyut jantung yang dapat diraba pada lokasi arteri yang berada di bawah kulit, seperti pada pergelangan tangan serta leher. Denyut jantung dihasilkan karena kontraksi otot jantung saat memompa darah. Kecepatan denyut jantung yang normal mempunyai periode kontraksi sebesar 0,40 dari siklus jantung. ${ }^{4}$

Sistem saraf simpatis yang mengontrol kerja jantung pada saat berolahraga, ketika dibutuhkan peningkatan aliran darah mempercepat frekuensi denyut jantung melalui efeknya pada jaringan pemacu. Efek yang utama stimulus simpatis pada nodus SA adalah percepatan depolarisasi sehingga ambang lebih cepat tercapai. Norefinefrin yang dikeluarkan dari ujung saraf simpatis mengurangi permeabilitas $\mathrm{K}^{+}$. Dengan penurunan jumlah ion kalsium yang meninggalkan sel-sel maka bagian dalam sel itu menjadi kurang negatif sehingga timbul efek depolarisasi. Pergeseran ke ambang yang lebih cepat memungkinkan potensial aksi menjadi lebih sering sehingga kecepatan jantung meningkat. Frekuensi denyut jantung terutama diatur oleh persarafan jantung, yaitu stimulasi simpatis meningkatkan frekuensi denyut jantung dan stimulasi parasimpatis menurunkannya.,56

Penelitian Irene Elly ${ }^{7}$ di Bandung memperoleh denyut nadi rata-rata awalnya adalah $72,09 \times$ / menit dan denyut nadi rata-rata setelah naik turun tangga adalah $74,49 \times /$ menit dengan uji t-berpasangan berbeda bermakna antara denyut nadi awal dan denyut nadi setelah naik turun tangga $(\mathrm{p}=\mathrm{o}, \mathrm{ooo})$.
Penelitian yang dilakukan oleh Ekelund dkk. ${ }^{8}$ di Orebro mendapatkan perbedaan signifikan $(\mathrm{p}<0,001)$ antara jenis kelamin dan heart rateoxygen uptake $\left(\mathrm{HR}-\mathrm{VO}_{2}\right)$ rata-rata. Peningkatan denyut nadi terjadi pada aktivitas fisik dengan penilaian relative peak oxygen uptakes $\left(\% \mathrm{PVO}_{2}\right)$ kategori rendah dan tinggi, pada laki-laki dan perempuan rata-rata denyut nadi pada latihan intensitas rendah adalah $120 \times /$ menit dan latihan intensitas berat adalah $160 \times$ /menit, namun pada laki-laki uptake oxygen lebih tinggi daripada perempuan.

Penelitian oleh Ayu Permata dkk. ${ }^{9}$ dinyatakan bahwa pelatihan interval intensitas tinggi lebih meningkatkan kebugaran fisik daripada senam aerobik high impact pada mahasiswa Program Studi D-III Fisioterapi, Universitas Abdurrab.

Penelitian yang dilaksanakan Nursin Muchlis $^{10}$ pada mahasiswa laki-laki angkatan 2011-2014 Fakultas Kedokteran Universitas Muhammadiyah Palembang tahun 2014 didapatkan peningkatan pulse rate rata-rata setelah melakukan Harvard test adalah $61,8 \pm 7,236 \times / 30$ detik.

Penelitian ini bertujuan mengetahui pengaruh latihan interval intensitas tinggi terhadap denyut nadi mahasiswa Fakultas Kedokteran Universitas Muhammadiyah Palembang.

\section{Metode}

Penelitian pengaruh latihan interval intensitas tinggi terhadap denyut nadi tersebut dilaksanakan secara observasional memakai metode kuasi eksperimental dengan pretest-posttest design. Penelitian dilakukan pada bulan November sampai dengan Februari 2016 di Laboratorium Fisiologi, Fakultas Kedokteran (FK), Universitas Muhammadiyah Palembang. Sampel diperoleh dari mahasiswa Fakultas Kedokteran, Universitas Muhammadiyah Palembang dengan memakai teknik pengambilan simple random sampling sesuai kriteria. Sebanyak 6o sampel penelitian yang diambil memenuhi kriteria inklusi, yaitu usia 18-23 tahun, laki-laki, tidak merokok dan tidak termasuk kriteria eksklusi penelitian, yaitu atlet serta mempunyai riwayat penyakit jantung dan paru.

Analisis data menggunakan data primer dari hasil pengukuran denyut nadi secara langsung setelah melakukan latihan interval intensitas tinggi, kemudian data dianalisis secara deskriptif dan disajikan dalam bentuk tabel. 
Tabel 1 Distribusi Frekuensi Responden berdasar atas Usia

\begin{tabular}{cccc}
\hline Usia (tahun) & Frekuensi $(\mathbf{n}=60)$ & Persen & Rata-rata (tahun) \\
\hline 18 & 10 & 17 & $19,97 \pm 1,273$ \\
19 & 10 & 17 & \\
20 & 18 & 30 & \\
21 & 18 & 30 & \\
22 & 2 & 3 & \\
23 & 2 & 3 & \\
\hline
\end{tabular}

\section{Hasil}

Berdasar atas Tabel 1 diketahui bahwa rentang usia responden adalah 18-23 tahun. Usia ratarata responden $19,97 \pm 1,273$ tahun. Distribusi usia yang paling banyak pada usia 20-21 tahun.

Berdasar atas Tabel 2, denyut nadi sebelum latihan intensitas tinggi adalah $85,33 \pm 10,993 \times /$ menit dan denyut nadi rata-rata setelah latihan interval intensitas tinggi adalah $152,00 \pm 8,975 \times$ / menit. Setelah dilakukan uji normalitas ShapiroWilk diketahui bahwa sebaran data untuk denyut nadi sebelum $(\mathrm{p}=0,585)$ dan denyut nadi setelah latihan interval intensitas tinggi (nilai $\mathrm{p}=0,405$ ). Dengan demikian, disimpulkan bahwa distribusi kedua kelompok data adalah normal sehingga uji hipotesis yang digunakan adalah uji T-dependent.

Dari hasil uji statistik T-dependent antara denyut nadi sebelum dan denyut nadi setelah latihan interval intensitas tinggi didapatkan nilai $\mathrm{p}=0,000(\mathrm{p}<0,005)$ sehingga dapat disimpulkan terdapat pengaruh latihan interval intensitas tinggi terhadap denyut nadi.

\section{Pembahasan}

Dari hasil penelitian didapatkan pengaruh latihan interval intensitas tinggi terhadap denyut nadi pada mahasiswa Fakultas Kedokteran Universitas Muhammadiyah Palembang. Hasil penelitian ini sama dengan penelitian yang dilaksanakan oleh Ekelund dkk., ${ }^{8}$ Irene Elly, ${ }^{7}$ Ayu Permata dkk., ${ }^{9}$ dan Nursin Muchlis ${ }^{10}$ yang mayoritas juga mendapatkan peningkatan denyut nadi setelah melakukan latihan fisik.
Faktor-faktor yang memengaruhi peningkatan denyut nadi adalah usia, jenis kelamin, keadaan dan riwayat kesehatan, intensitas dan lama kerja, sikap kerja, faktor fisik, serta kondisi psikis. ${ }^{11}$ Pada penelitian ini faktor yang memengaruhi peningkatan denyut nadi salah satunya adalah intensitas dan lama kerjanya karena berat atau ringannya intensitas kerja berpengaruh terhadap denyut nadi. Lama kerja, waktu istirahat, dan irama kerja yang sesuai dengan kapasitas optimal manusia akan ikut memengaruhi frekuensi nadi sehingga tidak melampaui batas yang maksimal. Apabila melakukan pekerjaan yang berat dan dalam waktu lama akan mengakibatkan denyut nadi bertambah cepat apabila dibanding dengan melakukan pekerjaan yang ringan dan dalam waktu singkat. ${ }^{11}$

Latihan interval intensitas tinggi ini terdiri atas periode melakukan intensitas tinggi yang diselingi dengan periode istirahat aktif, yaitu intensitas rendah. Keadaan ini menyebabkan tubuh secara efektif akan membentuk dan mempergunakan energi yang didapatkan dari sistem anaerobik. Penambahan interval membantu pembuangan metabolisme dari otot selama periode istirahat pada saat latihan interval intensitas tinggi sedang dilakukan oleh tubuh. Perubahan periode latihan yang dilakukan bergantian ini membantu tubuh meningkatkan volume dalam hal mengonsumsi oksigen saat latihan pada volume dan kapasitas maksimum $\left(\mathrm{VO}_{2} \max \right)$ selama latihan. ${ }^{3}$

Aktivitas fisik sepertilatihan intervalintensitas tinggi akan memengaruhi denyut nadi seseorang. Denyut nadi merupakan rambatan dari denyut jantung yang dihitung tiap menitnya. Sistem saraf

Tabel 2 Denyut Nadi Sebelum dan Setelah Latihan Interval Intensitas Tinggi

\begin{tabular}{lcccc}
\hline Denyut Nadi & Rata-rata & SD & SE & p \\
\hline Sebelum latihan & 85,33 & 10,993 & 2,007 & 0,585 \\
Setelah latihan & 152,00 & 8,975 & 1,639 & 0,405 \\
\hline
\end{tabular}


simpatis yang mengontrol kerja jantung pada saat olahraga, ketika dibutuhkan peningkatan aliran darah dan mempercepat frekuensi denyut jantung melalui efeknya pada jaringan pemacu. Efek yang utama stimulus simpatis pada nodus SA merupakan percepatan depolarisasi sehingga ambang lebih cepat tercapai. Norefinefrin yang dikeluarkan dari ujung saraf simpatis mengurangi permeabilitas $\mathrm{K}^{+}$. Dengan penurunan jumlah ion kalsium yang meninggalkan sel, bagian dalam sel menjadi kurang negatif sehingga timbul efek depolarisasi. Pergeseran ke ambang yang lebih cepat memungkinkan potensial aksi itu menjadi lebih sering dan karenanya kecepatan jantung meningkat. ${ }^{5}$

Dengan peningkatan fungsi kardiovaskular maka akan didapatkan efisiensi nutrisi dan oksigen selama pembentukan ATP. Oleh karena itu, pada orang dengan waktu terbatas untuk melakukan aktivitas fisik rutin, perlu melakukan latihan interval intensitas tinggi, yaitu kombinasi latihan intensitas tinggi dan latihan intensitas yang rendah sehingga dapat meningkatkan daya tahan sistem kardiovaskular, kapasitas paru, kebugaran fisik, dan memengaruhi peningkatan denyut nadi.

Bagi penelitian selanjutnya diharapkan dapat diteliti variabel yang kemungkinan berhubungan dengan peningkatan denyut nadi. Memberikan penyuluhan kepada seluruh masyarakat seperti mahasiswa dengan aktivitas yang padat untuk melakukan latihan fisik teratur terutama dengan latihan interval intensitas tinggi.

\section{Simpulan}

Denyut nadi meningkat setelah dilakukan latihan interval intensitas tinggi yang berarti terdapat pengaruh latihan interval intensitas tinggi itu terhadap denyut nadi mahasiswa FK Universitas Muhammadiyah Palembang.

\section{Daftar Pustaka}

1. Astorino TA, Allen RP, Roberson DW, Jurancich M, Lewis R, McCarthy K, dkk. Adaptations to high-intensity training are independent of gender. Eur J Appl Physiol. 2011;111(7):1279-86.
2. Astorino TA, Allen RP, Roberson DW, Jurancich M. Effect of high intensity interval training on cardiovascular function, VO2max, and muscular force. J Streght Cond Res. 2012;26(1):138-45.

3. Kolt GS, Snyder-Mackler L, penyunting. Physical therapies in sport and exercise. Edisi ke-2. London: Churcill Livingstone; 2007.

4. Rachman RY, Hartanto H, Novrianti A, Wulandari N, penyunting. Guyton \& Hall buku ajar fisiologi kedokteran (terjemahan). Edisi ke-11. Jakarta: EGC; 2007.

5. Sherwood L. Fisiologi manusia dari sel ke sistem (terjemahan). Edisi ke-8. Jakarta: EGC; 2014.

6. Ganong WF. Buku ajar fisiologi kedokteran. Edisi ke-22. Jakarta: EGC; 2008.

7. Irenne Elly MS. Perubahan denyut nadi pada mahasiswa setelah aktivitas naik turun tangga (skripsi). Fakultas Kedokteran Universitas Diponegoro Semarang. 2006 [diunduh 30 Mei 2016]. Tersedia dari: http://eprints. undip.ac.id/20417/1/Irenne.pdf.

8. Ekelund U, Poortvliet E, Yngve A, HurtigWennlöv A, Nilsson A, Sjöström M. Heart rate as an indicator of the intensity of physical activity in human adolescents. Eur $\mathrm{J}$ Appl Physiol. 2001;85(3-4):244-9.

9. Ayu Permata, I Wayan Weta, Muh. Ali Imron. Pelatihan interval intensitas tinggi lebih meningkatkan kebugaran fisik daripada senam aerobik high impact pada mahasiswa Program Studi D-III Fisioterapi Universitas Abdurrab (tesis). Program Pascasarjana, Universitas Udayana Denpasar. 2015 [diunduh 25 Mei 2016]. Tersedia dari: http:// tinyurl.com/ayu-permata.

10. Nursin Mukhlis. Physical fitness mahasiswa laki-laki angkatan 2011-2014 di Fakultas Kedokteran Universitas Muhammadiyah Palembang tahun 2014 (skripsi). Palembang: Jurusan Fakultas Kedokteran UMP; 2014.

11. Muffichatum. Hubungan antara tekanan panas, denyut nadi dan produktivitas kerja pada pekerja pandai besi Paguyuban Wesi Aji Dororejo Batang (skripsi). Jurusan Ilmu Kesehatan Masyarakat, Fakultas Ilmu Keolahragaan, Universitas Negeri Semarang. 2006 [diunduh 21 Mei 2016]. Tersedia dari: http://lib.unnes.ac.id/691/1/1262.pdf. 